\title{
Considerations FOR ACCEPTABILITY IN Bible translation
}

Author:

Diphus C. Chemorion ${ }^{1}$

\section{Affiliation:}

${ }^{1}$ Department of Biblical

Studies, Theology and

Philosophy, St Paul's

University, Kenya

\section{Correspondence to:}

Diphus Chemorion

e-mail:

dchosefu@stpaulslimuru. ac.ke

Postal address:

St. Paul's University, Private Bag 00217, Limuru, Kenya

\section{Keywords:}

Bible translation; acceptability; Great

Commission; interpretation; linguistics

\section{Dates:}

Received: 25 June 2008

Accepted: 20 Oct. 2009

Published: 16 Dec. 2009

How to cite this article:

Chemorion, D.C., 2009,

'Considerations for acceptability in Bible translation', Verbum et Ecclesia 30(2), Art. \#343, 5 pages. DOI: 10.4102 ve.v30i2.343

\section{This article is available} at:

http://www.ve.org.za

Note:

The author of this article, Dr D.C. Chemorion, is an alumnus of Stellenbosch University. This article is adapted from the author's dissertation that was submitted as fulfilment of the requirements for the degree Doctor of Theology at Stellenbosch University

(cf. Chemorion 2008). Dr Chemorion is a lecturer of Biblical and Translational Studies at St Paul's University, Kenya.

(C) 2009. The Authors. Licensee: OpenJournals Publishing. This work is licensed under the Creative Commons Attribution License.

\section{ABSTRACT}

The ministry of Bible translation is an important component of the Great Commission (Matthew 28:18-20) and its mandate is to reach everyone with the word of God. One of the main goals of a Bible translation project is to produce a translation that will be used by the church in a given language group. Bible translation teams believe that the lives of the intended recipients will be changed positively when they gain access to Scripture in their own language. However, recent developments regarding Scripture use have shown that the success of any Bible translation project depends on whether or not its products are acceptable. If a translation is not acceptable to the intended audience, it may not be used, and as a result, it may fail to bring about the desired impact. This article explores the concept of 'acceptability' as used in Bible translation and highlights important considerations that translators need to keep in mind in order to enhance the acceptability of their translation products.

\section{INTRODUCTION \\ THE PHENOMENON OF ACCEPTABILITY IN BIBLE TRANSLATION ${ }^{1}$ 'Acceptability' as a principle in Bible translation}

In his article entitled 'Perceived authenticity: The fourth criterion of good translation', Andersen (1998) proposes that the fourth criterion for a good translation - in addition to accuracy, clarity and naturalness (Barnwell 1992:23) - is 'perceived authenticity'. ${ }^{2}$ He defines perceived authenticity as 'the receptor audience's perception that the text is an authentic and trustworthy version of the original message'. He argues that the receptor audience's evaluation of a translation is subjective, but if a translation that is properly done lacks the things the receptor language regards as the mark of authenticity, the translation may not be accepted (Andersen 1998:2). ${ }^{3}$

In response to Andersen's views, Larsen (2001:40-53) wrote an article entitled 'The fourth criterion of a good translation'. Larsen agrees with Andersen on the need to acknowledge the existence of the fourth criterion for a good (Bible) translation, namely that the receptor audience expects to see certain things in a translation before they can trust it as a true word of God. According to Larsen, accuracy, clarity and naturalness are well-known criteria for an objective evaluation of a translation, but the fourth criterion is different because it is concerned with how the intended receptor audience evaluates the text without necessarily having been trained in translation principles (Larsen 2001:40).

Larsen suggests that this fourth criterion should be called 'acceptability' and not 'perceived authenticity', as proposed by Andersen. Larsen's main reason for this shift of terminology is that 'a translation neither can nor should be authentic in the primary sense of that word, because a translation is different from original authorship' (Larsen 2001:42). To Larsen, the criterion of acceptability is essential in Bible translation. Using the analogy of a traditional three-legged African stool Larsen states: 'If accuracy, naturalness, and clarity are like the indispensable three legs of a stool, then acceptability is like the seat on the stool. You want to trust the legs to be solid but the seat should also be comfortable - and maybe even beautiful' (Larsen 2001:43-44).

Although the concept of 'acceptability' has only been articulated recently, issues of acceptability in Bible translation are as old as the practice of Bible translation. The history of Bible translation reveals that Scripture translations have always been characterised by questions regarding the acceptability of any given version of the Bible. Pioneer Bible translators such as St Jerome, John Wycliffe, Erasmus, Martin Luther and William Tyndale had both admirers and persecutors who viewed their translations from different perspectives. According to Glassman (1981:12), 'practically none of the pioneer translations of the Bible ever saw light of day without incurring the displeasure of many detractors'. Even today, no mother tongue translation of the Bible can be used effectively unless it is acceptable.

\section{The subjective nature of acceptability}

As noted in the previous section, both Andersen and Larsen agree that the notion of 'acceptability' as an additional criterion for a good translation is very subjective in nature. Their position has also been supported by other scholars. According to Van der Merwe (2003:6), 'it is the perceptions and individual expectations of people that determine how people respond to new translations, and not necessarily

1.cf. Chemorion (2008:20ff).

2.Translators affiliated to the Summer Institute of Linguistics (SIL) hold the view that a good translation is a meaning-based (idiomatic) translation, which can be achieved through the criteria of accuracy of meaning, clarity of sentence construction, and naturalness of expression. These three criteria are expected to increase the level of intelligibility of a translation. While articulating the dynamic/ functional theory of translation, Nida \& Taber (1974:12) explain that 'translation consists of reproducing in the receptor language the closest natural equivalent of the source language messan' the closest natual the lead to greater acceptability and that a perfectly intelligible translation may not be acceptable, while a badly done translation may be
embraced (Nida 1988:301-308).

3.Andersen identifies three different kinds of proofs of authenticity, namely stylistic features, certification by a checking procedure, and the credibility of the translator. 
the inherent merits of the translation'. Nord (2001:188) refers to the subjective views of the receptor audience as 'subjective theories', which she also describes as a people's perception of reality that is dependent on the knowledge and experience drawn from one's culture. According to Nord (2001:187), one's cultural background and established conventions shape how one perceives reality. She therefore argues that the target text recipients may, on the basis of their subjective theories, judge a translation as either excellent or poor even when they have not compared it with the corresponding source text.

In general, it can be stated that the acceptability of a translation depends on the client's evaluation of the translation as either useful or not with regard to the desired communicative function of the translation. It is difficult to measure acceptability in precise and objective terms. Nevertheless, there are certain indicators which may help translators determine whether or not the translation is acceptable. Three of the most important indicators of an accepted translation are explained in the following section.

\section{Manifestations of acceptability}

The first manifestation of the acceptability of a translation is when people have a compelling desire to acquire a copy of the translation once it is published ${ }^{4}$. People will not spend their money on buying a copy of a translation unless they consider it valuable and necessary for them to possess. In situations where a translation is acceptable, Christians in particular would want to purchase their own copies of the mother tongue translation as their primary resource for spiritual nourishment. Sometimes even illiterate elderly people buy the translation so that their children or grandchildren can read it to them. On the contrary, when a translation is not acceptable, it would become difficult to sell because people may not want it. ${ }^{5}$

The second manifestation of acceptability of a translation occurs when those who bought the translation actually use it. It is one thing to buy a translation out of initial excitement and another thing to find it essential for daily use. When a translation is acceptable, people will use it for several purposes, some of which are listed in Conradie et al. (1995:1-2). According to these authors, people read the message in the Bible in order to reflect on it and apply it to their lives. For this reason the Bible is read in church or during personal and family devotions. It is also read in schools and political gatherings or elsewhere (Conradie et al. 1995:1). These authors go on to explain:

The Bible, for example, plays an important role in the worship of Christian congregations. The Bible is not only read, explained and applied in Christian liturgies: biblical phrases also play a role in the worship itself. It provides the vocabulary for many of the prayers and hymns. Christian hymns may even be called the "Bible of the laity" since they present an already and relatively simple "Bible" to the laity. To a certain extent Christian hymns provide the "spectacles" through which the Bible is read.

(Conradie et al. 1995:1-2)

The third manifestation of acceptability of a translation occurs when certain aspects of the translation begin to affect the life of the people in general. For example, some people may become converted to Christianity after reading parts of the translated Scripture. Other people, especially the illiterate, may memorise certain verses from the translation and quote them when necessary. Those who sing may compose songs from translated

\footnotetext{
4.cf. the discussion on best ways of judging a published sample material in Nida \& Taber (1974:172-173)

5.Smalley (1991:217) gives several reasons why people may not want a translation in their own language: 'Perhaps it is not an idiomatic translation, or it is difficult to understand or unpleasent to read, or perhaps people believe that a Bible in a foreign language is superior, or that a different dialect would be more suitable, or perhaps language is superior, or that a different dial.'

6.For more information on how a translation of the Bible is used refer to Smalley (1991:224-233)
}

texts and some people may adopt the vocabulary used in the translation in their daily conversation with other believers. In other words, when people like a particular translation, they tend to internalise its contents and apply it to practical daily life. When the translation is popular, it becomes deeply rooted in people's lives. People will discuss what they have heard or read and retell in their language some of the passages that they find most interesting. They also share the stories with their children. People who regard the Bible as containing God's guidelines for proper human existence allow the Bible to govern their behaviour patterns. In that case the translation would be respected as a behavioural guide for Christian individuals and communities. It therefore goes without saying that when a translation is accepted and correctly used, it can have a positive impact on the receptor audience as they strive to lead lives that are concordant with what they understand the biblical message to be.

\section{CONSIDERATIONS FOR ATTAINING ACCEPTABILITY IN BIBLE TRANSLATION}

The characteristics of acceptability as suggested in the preceding sections suggest that clients are attracted to translations that have greater utility value for them. In general it may be argued that people tend to have subjective views on what they consider to be an acceptable translation. Therefore, in order to achieve the acceptability of a translation, translators need to account for the target audience's subjective views. Below are some of the aspects that translators should consider in their quest to secure widespread acceptability of their translations.

\section{The significance of target audience participation}

Each target audience into whose language a translation is to be produced has two possible roles to play in the translation process. Firstly, the target audience may play a passive role as the addressees of the translation, just waiting for the finished product. In this case the target audience is not a major decision maker as to what type of translation needs to be done. Secondly, the target audience could play the more active role of being the 'initiator ${ }^{7}$-cum-addressee' of the translation. By doing so, the target audience is the one that designs the translation brief ${ }^{8}$ in conjunction with the translation team. The role of initiator affords the target audience the opportunity to participate in establishing the vision of the translation project as well as in planning, implementing and evaluating the translation process. The involvement of the receptor audience in the translation process is a prerequisite for ownership of the translation project and its products.

The emerging consensus among Bible translation scholars is that the translation team and genuine representatives of the receptor audience should make technical decisions pertaining to the actual product of the translation jointly. In the recent past, some scholars have argued that the intended readership of the translation should be given adequate opportunity to make an input concerning the type of translation that should be produced. For instance, Wendland (2002:183-184, 2004:25-26) observes that in the past, translation theory noted the importance of the intended readership, but often in a unilateral or even monolithic sort of way, in which the act of communication was viewed as a message transmission in one direction, where the author or translator contributes more or less everything, and the audience simply receives the text, interprets it and then decides how to respond.

7.In this article, the term 'initiator' is used interchangeably with the term 'client'. Nord (1997:139) defines an initiator of a translation as 'the person or group of people or institution that starts off the translation process and determines its course by defining the purpose for which the target text is needed".

8.According to Nord (1997:137), a 'translation brief' is a 'definition of the communicative purpose for which the translation is needed. The ideal brief provides implicit or explicit inform the medium over which it is to be trantent, the prospective place and time necessary, motive of production or reception of the text'. 
According to Wendland, recent studies have shown that communication (in text production or translation) needs to be

a truly shared process in which an audience (as an active consumer of the message) brings to a text their own distinct expectations, values, norms, biases, experiences, perspectives, and cognitive frameworks, all of which greatly influence either to foil or to facilitate the message that they perceive, understand and ultimately react to.

(Wendland 2002:184)

For this reason, Wendland urges that planners and organisers of Bible translation should not simply anticipate or overlook the intended target audience:

Rather, they must make every effort to find out beforehand the specific nature of their listenership/readership - not only their perceived needs, but their actual expressed needs and goals for the translation.

(Wendland 2002:184)

The above discussion suggests strongly that Bible translation organisations should not assume that a particular type of translation is suitable for the whole community simply because it is the type of translation preferred at organisational level. Rather, the translation agency should work jointly with representatives of the intended audiences from the target language community to identify a type of translation that is best suited for each audience. Harriet Hill has also stressed this point by cautioning translators against thinking that they are best suited to design translation products on behalf of the community they serve. In her view, translators should discuss with the community the pros and cons of various approaches of translation and leave the community to choose what is best for them (Hill 2006:179).

\section{The need for an audience/client-oriented purpose of translation}

One of the main principles held in functionalist theories of translation is that translations are meant to carry out certain communicative functions, which are ideal for certain types of audiences. From the perspective of functionalist theories, the skopos (purpose) of a translation may be regarded as the central criterion for determining the acceptability of a translation. Hans J. Vermeer, who was the founder of the skopos theory, maintained that a translation is produced for a given purpose, which it should serve (Nord 1997:27). According to Vermeer, translators need to observe the skopos rule, which is the following:

Translate/interpret/speak/write in the way that enables your text/ translation to function in the situation in which it is used and with the people who want to use it and precisely in the way they want it to function.

(Nord 1997:29)

The main implication of the skopos rule is that for a translation to be acceptable, it must serve the purpose for which it was needed. In other words, a translation is acceptable when the intended recipients consider it valuable and appropriate for their situation.

The need to have a translation skopos that is client-oriented is also emphasised by Nord, who regards the notion of function as an overriding criterion for her translation model (Nord 1991:4). In Nord's view a functional translation is one that fulfills the intended communicative purpose as defined by the client or commissioner in the translation brief (Nord 1999). Put differently, a functional translation is one that responds to the 'expectations, needs, previous knowledge, and situational conditions' of the receiver for whom it is intended (Nord 1997:28). Since different types of translations are needed for different functions, it is necessary for translators to determine the function for which a particular audience needs a translation and the nature of the translation that would be most suitable for that function.

It is important to note that a translation that is produced without considering the functional preferences of the receptor audience may be regarded as having an inappropriate skopos, however accurate, clear or natural it may be. The appropriateness of the translation skopos is therefore an important consideration, which should be determined before the translation process starts.

\section{Loyalty to the initiator of the translation and the source text author}

In her theoretical framework of translation, Nord states that translators should also observe an ethical principle, which she calls 'function-plus-loyalty' (Nord 1997:126). This principle requires the translator to be accountable to both the author of the source text and the initiator (or client) of the target text. The 'function-plus-loyalty' principle is therefore meant to serve as an ethical reminder for the translator not to act arbitrarily but to be committed bilaterally to both the target text requirements and the intentions of the source text sender. When a target audience performs the role of initiator for its own translation, it has an opportunity to determine the function for which it would like to have a translation. Acceptability of the translation can, therefore, be boosted if the translator fulfills the expectations of the target audience. However, the principle of 'function-plusloyalty' restrains the translator from producing a translation that unilaterally fulfills the expectations of the receptor audience while violating the original intentions of the source text author (Nord 1997:126). In other words, translators have a moral responsibility of addressing the expectations of the receptor audience genuinely, while ensuring that the message of the source text is not distorted unnecessarily.

The principle of 'function-plus-loyalty' is of great significance in the field of Bible translation because it protects the integrity of Scripture. Since many Christians believe that the Bible is the inspired word of God, they would resist any rendering that appears to contradict what the original authors of the Bible actually said. When effectively applied, the principle of 'function-plus-loyalty' will not only hold translators accountable for the kind of decisions that they make during the translation process, but it will also make the translation more acceptable.

\section{Consideration of cultural norms and existing} conventions

The concept of culture is one of the aspects of human life that can easily be described but which is not easily defined. The English anthropologist Edward Bernett Taylor formulated one of the oldest and most quoted definitions of culture. In his definition he states: 'Culture is that complex whole which includes knowledge, belief, art, morals, law, customs and any other capabilities and habits acquired by man and as a member of society' (Taylor as quoted in Katan 2004:25). Katan (2004:25) suggests that culture needs to be understood as a shared system for interpreting reality and organising experience. He also refers to culture as a shared mental model or map of the world. In his discussion on translators as cultural mediators, Katan (2004:7-23) sees translators as cultural mediators who should be able to understand and recreate culturally bound frames, wherever necessary, for easy and meaningful understanding of translations. He highlights the need for translators to understand the frames of interpretation in the source culture and be able to produce a translation which would create a comparable (rather than equivalent) set of interpretation frames to be accessed in the target reader's mind. ${ }^{9}$ It is, therefore, very important for translators to note that in as far as written texts are concerned, each culture has its own habits, norms and conventions which shape the understanding of written information. As Nord (1997:66) observes, the differences in the norms and conventions create translation problems that must be solved for the translations to be acceptable.

The task of Bible translation necessarily involves the reexpression of culturally bound information from a biblical

9.For further information on cultural frames of reference see Bascom (2003:81-111) and Wendland (2008:19-35) 
source text language using the target text language within its target text cultural setting. In other words, Bible translators mediate between the source text author and the target text audience. The cultural information that is often encountered in the translation process includes proper names, key terms, symbolic actions, animals, tools, festivals, etc. Since cultures are bound to be different in many respects, Bible translators have to adjust the culturally conditioned message of the Scriptures to fit into the contemporary culture. In order for the biblical cultural information to be meaningful in the target text culture, the translator needs to supply a code that makes appropriate sense in the target text culture. However, there are some things that would look extremely strange and complex to comprehend because they are culture specific. Agar (1991:168 cited in Nord 1997:25) refers to such things as the 'rich points' of a particular culture. Adopting Agar's perspective on the notion of 'rich points', Nord cautions translators to be sensitive to cultural differences between the source culture and the target culture in order to realise a successful intercultural translation. If the translation of cultural ideas is not handled appropriately, the target text readers may mistrust the translation, especially if they think culturally equivalent terms have deliberately been ignored. Examples to illustrate this point are given below.

Before the New Testament was translated into the Sabaot language $\mathrm{e}^{10}$, the Sabaot people were already exposed to biblical literature, especially the literal versions of the Bible that exist in Kiswahili and English. Over the years, the Scriptures had come to be understood in certain ways that created preconceived opinions on how certain texts were to be understood and translated. Although there was no written translation into the Sabaot language, some piecemeal renderings of the cultural concepts had been attempted orally through exposure to other language versions such as the Swahili Union version. ${ }^{11}$ When the Sabaot New Testament was published in 1997,, ${ }^{12}$ some of the Sabaot Christians and church leaders expressed their dissatisfaction with regard to how some of the key biblical terms were translated. They complained that the translators left out culturally familiar concepts and used other renderings, which they considered inappropriate. For example, in the Sabaot New Testament, the word 'prophet' was translated with a descriptive phrase as ng'älooltooyiintëëtaab Yëyiin ${ }^{13}$ which means a 'spokesman of God'. However, ordinary Sabaot Christians in their normal speech simply refer to the word 'prophet' as wöörkooyoontëët, which is a local term for a traditional Sabaot 'prophet' or seer. Another example is the translation of Jesus' title 'Son of man'. It was translated as Chiitaab Barak, ${ }^{14}$ which means a 'person from heaven' yet ordinary Sabaot Christians orally refer to 'Son of man' as wëritaab chii, which means 'Son of a person'. Similarly the preferred cultural equivalent for the word 'priest' is tisiintëët (one who presides over traditional rituals) but in the Sabaot New Testament it was translated as bë̈liintëëtaab körösëek, ${ }^{15}$, which means burner of incense. During a Sabaot Bible key terms workshop that was held in August 2008, participants strongly expressed the need for translators to consider using familiar and culturally acceptable terms in the ongoing revision of the Sabaot New Testament. ${ }^{16}$

10. The Sabaot people live on the slopes of Mt. Elgon along the Kenya-Uganda border They are categorized linguistically as part of the Kalenin family of the Southern Nilotic cluster of languages (Larsen 1986:143). The Sabaot New Testament was published by Bible Translation and Literacy (BTL) in 1997.

11.According to Lefevere (1992:114), translations such as religious texts tend to acquire a timeless quality of their own, and readers do not easily part from them. They come to trust the translation for no other reason than their familiarity with it. They come to trust the translation for no other reason than their familiarity with it.
Readers often feel reluctant to switch to another, newer translation, even if experts Readers often feel reluctant to switch to another, newer translation, even if experts
have pronounced it better. In Lefevere's view, the Septuagint has survived because of this reason even if it may not have been done well.

12. The New Testament, Sabaot translation, Bible Translation and Literacy, Nairobi.

13.See for example Matthew 2:15 in the Sabaot New Testament.

14.See for example Matthew 8:20 in the Sabaot New Testament.

15.See for example Matthew 8:4 in the Sabaot New Testament.

16. The Sabaot key terms workshop was organised by the staff of Sabaot Bible Translation Project and the writer of this article was one of the facilitators.
Apart from looking for appropriate ways for re-expressing cultural ideas, translators need to consider appropriate target language conventions. In every culture, there are certain established conventions or accepted standards for measuring the quality of translations. Cultures gradually develop or adopt genre conventions, which characterise how different types of literature are organised within a particular cultural group (Nord 1997:53, 127). The prevailing concept of translation can influence the type of translation that the intended audience expects (Nord 1997:125). For this reason, translations that are produced in a manner that contradicts the regular conventions for doing translations face the risk of being rejected by the people for whom they are intended. It is therefore very important for Bible translators to be familiar with existing translation conventions within the receptor culture and try to conform to them as much as possible. If the skopos of the intended translation must be discordant to the prevailing conventions in translation, the translator has the obligation of explaining to the initiator of the translation the reason for producing an unorthodox translation. For acceptability of the translation to be achieved, the translator and the initiator of the translation must be in agreement concerning the nature of the intended translation before the actual drafting of the translation begins.

\section{Consideration of language and literacy issues}

One of the most important features of the intended translation that should be highlighted in the translation brief concerns the chosen medium of translation. Before attempting to translate the Bible into any language, the translator needs to find out the community's attitude towards their own language (Chemorion 2008:93). Studies on attitudes towards local languages in Nigeria have shown that many speakers of both majority and minority ethnic languages do not believe that their languages can be used for any serious conduct of modern-day affairs (Adegbite 2004:90). Among the elite in Nigeria, the English language is held in high esteem because parents believe that it has a higher socio-economic value. A child's mastery of English is not only an indication of higher social class, but it is also considered the key to good employment. According to Adegbite (2004:93), 'some parents in the elite group go to the extent of banning their children from using their mother tongue at home even though both parents speak the same language' and 'in certain schools, indigenous languages, pejoratively called 'vernaculars' are highly prohibited in preference for English'. However, a study on the attitudes towards ethnic languages among university students indicated that many students developed a positive attitude towards their mother tongue after attending lectures aimed at promoting the use of mother tongue (Adegbite 2004:91). The negative attitude towards ethnic languages is not only found in Nigeria but in many other African countries. If people have a negative perception of their own mother tongue they are likely to reject Scripture that has been translated into their language. In some cases, communities may look down upon a Bible translation in their own language simply because they think that their vernacular is not sacred enough for it to be used in translation (Smalley 1991:87). It is therefore worthwhile for translators to consider promoting positive attitudes towards the target language in order for the translation to gain wider acceptability.

Translations that are rendered using dialects that are viewed as inferior stand a high risk of being despised and rejected. According to Dye (2003:6), people only read Scripture in a particular language if they are pleased to use that language for that purpose. Dye explains that in order for the translation to be acceptable, the language used in the translation should be considered a valid medium for Scripture and the intended audience should not consider it to be unimportant or inappropriate. The translators should therefore ensure that the dialect chosen for translation is acceptable to the audience.

Besides the question of the suitable dialect to be used in the translation, the translator must also consider the level 
of vocabulary that would be most suitable for the intended audience. A translation that is full of obsolete terms or archaic expressions that are only known to the elderly may not be useful to the youth, who are only used to contemporary vocabulary of their language. Similarly, a translation that sounds childish may be rejected by educated or older people who know the language very well. Therefore, before the translation is produced, the translators should carry out serious sociolinguistic research and testing in order to gauge the level of vocabulary that would be suitable and acceptable to the receptor audience.

The translator should also consider the level of literacy in the receptor language. As Sterk and Muthwii (2004:151) noted, '[c]rucial to the success of a publication is the knowledge that there is a readership for it, and that these potential readers are willing to purchase the translation'. If the writing system of the receptor language has been established only recently it is very likely that many people are not yet literate in their language. In that case, illiterate people will only have access to mother tongue translation through an oral-aural medium. The translator must therefore produce a translation that is easy for public reading and hearing. Such a translation needs to be written in simple style and easy vocabulary so that the reading would be fluent for the benefit of illiterate people.

\section{CONCLUSION}

This article has highlighted the significance of acceptability in Bible translation and some of the considerations relevant to translators in order to produce acceptable translations. In summary, it can be stated that whether or not a translation is acceptable depends on the intended audience's subjective preferences and not necessarily on objective assessment of a translation. In most cases, the subjective feelings of the receptor audience revolve around the purpose for which they need a translation. It therefore follows that a translation that fulfils the expectations of the intended audience has a good chance of being accepted.

\section{REFERENCES}

Adegbite, W., 2004, 'Enlightenment and attitudes of the Nigerian elite on the roles of languages in Nigeria', in M.J. Muthwii \& A.N. Kioko (eds.), New language bearings in Africa: A fresh quest, pp. 89-100, Multilingual Matters, Clevedon.

Andersen, T.D., 1998, 'Perceived authenticity: The fourth criterion of good translation', Notes on Translation 12(3), $1-13$.

Bascom, R., 2003, 'The role of culture in translation', in T. Wilt (ed.), Bible translation frames of reference, pp. 81-111, St Jerome, Manchester.

Barnwell, K., 1992, Manual for Bible translation: Introductory course on translation principles, Summer Institute of Linguistics, Dallas.

Chemorion, D.C., 2008, 'Translating Jonah's narration and poetry into Sabaot: Towards a participatory approach to Bible translation (PABT)', Doctor of Theology dissertation, Stellenbosch University.

Conradie, E.M., Jonker, L.C., Lawrie, D.G., Arendse, R.A., 1995, Fishing for Jonah: Various approaches to biblical interpretation, University of the Western Cape, Cape Town.

Dye, T.W., 2003, 'Conditions necessary for Scriptures to be used', Word and Deed 2(2), 5-10.

Glassman, E.H., 1981, The translation debate: What makes a Bible translation good?, Intervarsity Press, Illinois.

Hill, H., 2006, The Bible at cultural crossroads: From translation to communication, St Jerome, Manchester.

Katan, D., 2004, Translating cultures: An introduction for translators, interpreters and mediators, St Jerome, Manchester.

Larsen, I., 1986, 'Sabaot Noun Classification', Nilo-Saharan, 6, 143-163.

Larsen, I., 2001, 'The fourth criteria of translation', Notes on Translation 15(1), 40-53.
Lefevere, A., 1992, Translating Literature: Practice, Theory in a Comparative Literature Context, The Modern Language Association of America, New York.

Nida, E.A., 1988, 'Intelligibility and acceptability in Bible translating', The Bible Translator 39(3), 301-308.

Nida, E.A. \& Taber, C.R., 1974, The Theory and Practice of Translation, Brill, Leiden.

Nord, C., 1991, Text Analysis in Translation: Theory, Methodology and Didactic Application of a Model for Translation-oriented Text Analysis, John Benjamins, Amsterdam.

Nord, C., 1997, Translating as a purposeful activity: Functionalist approaches explained, St Jerome, Manchester.

Nord, C., 1999, Translating as a Text Production Activity, viewed 3 Dec 2009, from http://www.humnet.unipi. it/traduzione_letteraria/download/bruti/Nord_ Translatingtextproduction.pdf

Nord, C., 2001, 'Royalty revisited: Bible Translation as a case in point', The Translator 7(2), 185-202.

Smalley, W.A., 1991, Translation as mission: Bible translation in the modern missionary movement, Mercer University Press, Macon.

Sterk, J. P. \& Muthwii, J.M., 2004, 'The publishing of Scriptures in Africa: Sociolinguistic challenges', in E.R. Wendland \& J. Loba-Mkole (eds), Biblical texts and African audiences, pp. 150-170, Acton, Nairobi.

Van der Merwe, C.H.J., 2003, 'A new translation of the Bible into Afrikaans. A theoretical and practical orientation', Unpublished presentation, Department of Ancient Studies, University of Stellenbosch.

Wendland, E.R., 2002, "Towards a "literary" translation of the Scriptures with special reference to a "poetic rendition"', in J.A. Naudé \& C.H.J. van der Merwe (eds.), Contemporary translation studies and Bible translation: A South African perspective, Acta Theologica, Supplementum 2, pp. 164-201, University of the Free State, Bloemfontein.

Wendland, E.R., 2004, Translating literature of Scripture: A literary rhetorical approach to Bible translation, Summer Institute of Linguistics, Dallas.

Wendland, E.R., 2008, Contextual frames of reference in translation: A course book for Bible translators and teachers, St Jerome, Manchester. 